\title{
Dr. Wigbert (Bert) Wiederholt
}

\author{
Douglas Galasko
}

Department of Neurosciences, University of California at San Diego, Calif., USA

Wigbert C. Wiederholt, MD, died at the age of 68 on Thursday, March 9, 2000, at his home in La Jolla, with family and friends at his side. Dr. Wiederholt, who served on the Editorial Board of Neuroepidemiology since 1996, left a legacy of clinical and scholarly activities. His clinical and scientific career took several turns and spanned wide interests, including numerous contributions to the epidemiology of neurodegenerative diseases. Wearing the hats of clinical neurologist, mentor to medical students, residents and fellows, and chair of the University of California at San Diego (UCSD) Department of Neurosciences, he was instrumental in the development and growth of clinical and research activities in neurology in San Diego.

Dr. Wiederholt was born in Bad Warmbrunn, Germany. His father and grandfather were physicians, and he followed in their footsteps, becoming a doctor, as did three of his younger brothers. Dr. Wiederholt came to the United States in 1954 on a Fulbright scholarship, and stayed on to make a career in academic medicine. After completing residency training in neurology at the Mayo Clinic, he was a faculty member at Mayo Clinic and then at Ohio State University. He received a Master of Science degree from the University of Minnesota in 1965. For his research in clinical electrophysiology in the early 1960s, he received the $\mathrm{S}$. Weir Mitchell Award from the American Academy of Neurology. He moved to UCSD as Professor of Neurosciences in 1972, and was an attending physician at the UCSD Medical Center and the Veterans Affairs Health System, San Diego. He twice served as
Department Chair in Neurosciences, from 1978 to 1983 and again from 1990 to 1993. In 1983-1984 he spent a sabbatical training in neuroepidemiology at the Mayo Clinic, during which he carried out important studies to clarify the relationship between Guillain-Barré syndrome and the swine flu vaccine.

From his long and distinguished career, during which he authored more than 100 articles in leading medical journals, several accomplishments stand out. Shortly after his arrival at UCSD, he helped to initiate systematic clinical and pathological research into Alzheimer's disease in San Diego. These efforts formed the foundation for one of the first federally funded Alzheimer's Disease Research Centers, and Dr. Wiederholt remained a key investigator at this center from 1985 to 1999 . In the mid-1980s, he traveled to China as part of a group of UCSD investigators and helped to initiate and set up a research project on the epidemiology of dementia in Shanghai. In the late 1980s he headed an epidemiologic study of dementia in San Diego. In the 1990s, he turned his energies to ALS and Parkinson-Dementia Complex of Guam. From 1997, he directed an NIH-funded research program whose goals included the clinical characterization of neurodegenerative disorders on Guam, risk factor measurement, neuropathology and molecular genetics. He developed an infrastructure to make multidisciplinary research feasible, and persuaded a group of investigators from across the USA to pool their talents to study these degenerative disorders. Dr. Wiederholt continued to run the Guam project and

\begin{tabular}{ll}
\hline KARGER & ( ) 2001 S. Karger AG, Basel \\
Fax +41613061234 & \\
$\begin{array}{l}\text { E-Mail karger@karger.ch } \\
\text { www.karger.com }\end{array}$ & $\begin{array}{l}\text { Accessible online at: } \\
\text { www.karger.com/journals/ned }\end{array}$
\end{tabular}

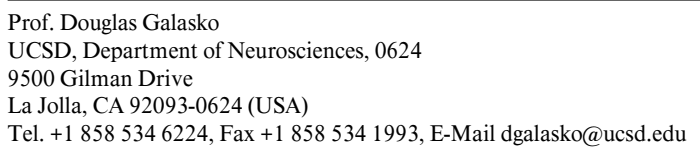


traveled to the island many times each year to evaluate patients, even when he faced advancing cancer and grueling chemotherapy.

He tried to demystify neurology, and was widely known for his book Neurology for Non-Neurologists, released in February 2000 in its fourth edition. A respected and beloved teacher, physician and researcher, Dr. Wiederholt was honored by a dinner in 1999, at which tribute was paid to his diverse contributions in the field of neurosciences. Speakers singled out his insightfulness, energy, drive and organizational abilities, as well as his extraordinary spirit and humanity, generosity, passion for work and life, and acerbic sense of humor. He was an avid reader, and attended and supported the theater, symphony, and opera in San Diego for many years. He was an adventurous traveler and took pride in having climbed Mt. Kilimanjaro at age 63 . He was passionate about tennis, at which he excelled. His forceful personality accepted few limitations, even in the face of the cancer that proved his greatest challenge.

Bert is sorely missed. Fortunately, strong memories live on among family, colleagues and friends, and in the many research endeavors that wear his imprint. 